\title{
STRATEGI KEPEMIMPINAN KEPALA DINAS DALAM MENINGKATKAN KINERJA PEGAWAI PADA DINAS PENDIDIKAN KOTA BANDA ACEH
}

\author{
Saiful Azmi ${ }^{1 *}$, Cut Zahri Harun ${ }^{1}$, Khairuddin $^{1}$ \\ ${ }^{1}$ Universitas Syiah Kuala, Indonesia \\ *e-mail: saifulloscules@gmail.com
}

\begin{abstract}
Abstrak
Sebuah instansi tentu memiliki seorang pemimpin. Kepemimpinan seorang pemimpin dapat menentukan arah dan tujuan organisasi. Penelitian ini bertujuan untuk mendeskripsikan program, strategi, dan faktor hambatan kepemimpinan Kepala Dinas Pendidikan Kota Banda Aceh dalam meningkatkan kinerja pegawai. Pendekatan penelitian yang digunakan yaitu kualitatif dengan metode deskriptif. Teknik pengumpulan data yaitu observasi, wawancara, dan dokumentasi. Subjek penelitian yaitu Kepala Dinas, Sekretaris, Kepala Sub Bagian, Kepala Bidang dan Kepala Seksi. Hasil Penelitian menunjukan bahwa Program peningkatan kinerja pegawai yaitu penerapan SOP, memberikan keteladanan, memberikan kesempatan berdiskusi, mengadakan kegiatan seminar, pelatihan, etos kerja, semangat kerja, pencapaian target, dan kerjasama pegawai. Strategi yang diterapkan yaitu kepemimpinan bersifat situasional bagi pegawai yang komintmen kerjanya biasa, meningkatkan etos kerja, memotivasi para pegawai, menginstruksikan pegawai membuat worksheet, mengunjungi setiap pegawai dan mengajak diskusi, dan menerapkan gaya kepemimpinan demokrasi. Faktor yang menjadi hambatan yaitu keterbatasan Sumber Daya Manusia (SDM), pegawai kurang terampil, kurang pengetahuan dan penggunaan teknologi terbatas.
\end{abstract}

Kata Kunci: Kepemimpinan; Kepala Dinas; Strategi; Program; Hambatan

\begin{abstract}
An agency certainly has a leader. The leadership of a leader can determine the direction and goals of the organization. This study aims to describe the programs, strategies, and factors that hinder the leadership of the Head of the Banda Aceh City Education Office in improving employee performance. The research approach used is qualitative with a descriptive method. Data collection techniques are observation, interviews, and documentation. The research subjects are the Head of Service, Secretary, Head of Sub Division, Head of Division, and Head of Section. The results showed that employee performance improvement programs provide outstanding opportunities for discussion, seminars, training, work ethic, work spirit, target achievement, and employee cooperation. The strategies applied are situational leadership for employees with regular work commitments, improving work ethic, motivating employees, instructing employees to make worksheets, visiting each employee and inviting discussions, and applying a democratic leadership style. Factors that become obstacles are limited Human Resources, less skilled employees, limited knowledge, and use of technology.
\end{abstract}

Keywords: Leadership; Head of Service; Strategy; Program; Obstacle

This is an open access article under the CC BY-SA license.

Copyright @ 2021 by Author. Published by Universitas Pendidikan Ganesha.

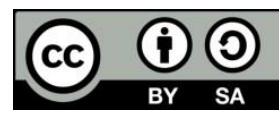

\section{PENDAHULUAN}

Sebuah organisasi tentu
memerlukan seorang pemimpin.
Pemimpin adalah seseorang yang
mempunyai keahlian memimpin,
mempengaruhi pendapat orang atau
sekelompok orang tanpa menanyakan
alasan-alasannya. Seorang pemimpin
adalah seseorang yang aktif membuat
rencana-rencana, mengkoordinasi,
melakukan percobaan, dan memimpin pekerjaan untuk mencapai tujuan bersama. Pengaruh seorang pemimpin dalam sebuah lembaga atau organisasi menentukan himbauan serta tujuan untuk mencapai visi dan misi. Pencapaian tujuan organisasi banyak aspek yang menjadi penting dalam pemenuhannya, diantaranya adalah unsur kepemimpinan atau pemimpin. Karena suatu instansi yang memiliki pegawai yang handal jika tidak dikelola dengan baik oleh pemimpin 
maka tidak akan dapat mencapai tujuan yang telah ditetapkan. Oleh sebab itu, pemimpin harus mampu mengelola Sumber Daya Manusia demi mencapai tujuan organisasi. Wahyudi (2017) menyatakan bahwa kepemimpinan dapat diartikan sebagai kemampuan seseorang dalam menggerakkan, mengarahkan sekaligus mempengaruhi pola pikir, cara kerja setiap anggota agar bersikap mandiri dalam bekerja terutama dalam pengambilan keputusan untuk kepentingan percepatan pencapaian tujuan yang telah ditetapkan. Hal ini juga senada dengan pendapat Hamalik (2016) bahwa seorang pemimpin memiliki beberapa peran diantaranya sebagai katalisator, fasilitator, dan sebagai motivator.

Seorang pemimpin memiliki program-program maupun strategi dalam proses kepemimpinannya. Kepemimpinan dikatakan sebagai proses mengarahkan dan mempengaruhi aktivitas-aktivitas yang ada hubungannya dengan pekerjaan para anggota kelompok. Jadi dasarnya kepemimpinan merupakan cara seorang pemimpin mempengaruhi bawahannya agar dapat bekerja sama dan bekerja efektif sesuai aturan bekerja. $\mathrm{Hal}$ penting lainnya adalah motivasi yang menjadi pendorong atau yang menggerakkan pegawai, supaya dapat bekerja sama secara produktif dan mencapai tujuan yang telah ditentukan.

Dalam organisasi, selain peranan seorang pemimpin yang sangat diperlukan, peranan pegawai juga merupakan peranan vital untuk membantu pemimpin dalam mencapai tujuan organisasi. Seperti yang diketahui dimana pencapaian tujuan suatu instansi diduga tidak terlepas dari disiplin para pegawai dan pimpinan dalam aktivitas kerja. Dengan demikian pemeliharaan maupun peningkatan kinerja para pegawai perlu dilakukan oleh seorang pemimipin pada suatu organisasi yang dipimpinnya. Agar sebuah tujuan organisasi berjalan dengan baik dan mencapai target. Hal ini juga berlaku di Dinas Pendidikan Kota Banda Aceh.

Berdasarkan hasil observasi yang dilakukan pada bulan Mei 2021, menunjukan bahwa adanya berbagai upaya positif yang dilakukan oleh Kepala Dinas dalam meningkatkan kinerja pegawai. Upaya tersebut baik melalui secara tertulis maupun secara lisan. Selain itu, pada dinas tersebut terdiri dari beberapa pegawai yang berbeda baik segi golongan, pangkat, jabatan, umur, budaya, suku, agama, dan kompetensi. Hal ini tentu menjadi suatu tantangan bagi Kepala Dinas untuk membagun sebuah hubungan kinerja antar sesama pegawai maupun antara Kepala Dinas dengan pegawai. Berdasarkan hasil observasi dan wawancara juga diperoleh informasi bahwa terdapat hambatan atau permasalahan Kepala Dinas Pendidikan Kota Banda Aceh dalam meningkatkan kinerja pegawai.

Hambatan tersebut diantaranya masih ada sebagian kecil Sumber Daya Manusia (SDM) di instansi tersebut tidak ingin meningkatkan kemampuan pengetahuan serta kedisiplinan diri. Selain itu mereka lebih menyelesaikan tugas dibandingkan bekerja dengan sepenuh hati dan tidak memikirkan kualitas pekerjaan yang dikerjakan. Kemudian juga sebagian kecil pegawai yang masih kurang pengetahuan tentang teknologi serta cara penggunaannya, seperti diketahui sekarang teknologi menjadi faktor penting untuk memudahkan pelayanan masyarakat dan menyampaikan informasi. Hal ini tentu tidak dapat dibiarkan berkelanjutan, mengingat perubahan zaman yang semakin cepat.

Hal ini juga sejalan dengan penelitian yang dilakukan oleh Al-barqi (2015) pada Kementerian Agama Kota Malang, dimana penelitian tersebut menunjukkan adanya kendala-kendala yang dihadapi oleh lembaga tersebut mengenai kinerja pegawai, diantaranya kurangnya kedisiplinan pegawai, pegawai tidak melaksanakan tugas sesuai bidangnya, kurangnya prestasi-prestasi yang dicapai, kurangnya komunikasi pegawai dengan pemimpin, dan keterbatasannya SDM yang dimiliki. Selain itu, penelitian serupa juga dilakukan oleh Frayudha et al., (2016) di Dinas Pendidikan Kabupaten Rembang 
yang dimana juga ditemukan berbagai masalah pada pegawai, diantaranya kurangnya kedisiplinan, kualitas kinerja, kualitas pelayanan, dan tidak menyelesaikan tugas sesuai Standar Opersional Prosedur (SOP).

Dari beberapa hasil temuan yang diperoleh sebelumnya dapat diketahui bahwa masih rendahnya kinerja pegawai di beberapa instansi pemerintah di beberapa daerah tersebut. sehingga perlu untuk dianalisis mengenai cara atau strategi, program, dan hambatan secara menyeluruh kepala lembaga/dinas dalam meningkatkan kinerja pegawai sehingga tercapainya tujuan instansi tersebut dan tercapainya tujuan pembangunan nasional.

Dengan demikian, hal ini menarik minat penulis untuk melakukan suatu penelitian tentang bagaimanakah strategi kepemimpinan dalam meningkatkan kinerja pegawai dengan judul "Strategi Kepemimpinan Kepala Dinas Dalam Meningkatkan Kinerja Pegawai Pada Dinas Pendidikan Kota Banda Aceh"

Alasan dilakukan penelitian ini adalah untuk mengkaji mengenai strategi apakah yang digunakan oleh Kepala Dinas Pendidikan Kota Banda Aceh dalam menyelesaikan permasalahan internalnya mengenai kinerja pegawai. agar hasil yang diperoleh menjadi suatu acuan dan referensi untuk pemimpin yang lain kedepannya, mengingat Banda Aceh merupakan salah satu kota yang terletak paling ujung barat Indonesia dan merupakan ibu kota provinsi Aceh yang memiliki nilai-nilai keistimewaan.

\section{METODE}

Penelitian ini menggunakan pendekatan kualitatif. Sedangkan metode menggunakan metode deskriptif. Terkait dengan kajian tersebut penelitian ini bertujuan untuk memperoleh gambaran tentang strategi, program, dan hambatan kepemimpinan Kepala Dinas dalam meningkatkan kinerja pegawai pada Dinas Pendidikan Kota Banda Aceh.

Populasi dalam penelitian ini berjumlah 67 orang. Sedangkan subjek penelitian yaitu terdiri dari 16 orang, diantaranya: Kepala Dinas, Sekretaris,
Subbagian Program Kepegawaian, dan Aset, Subbagian program dan Pelaporan, Kepala Bidang PAUD dan Pendidikan Non Formal, Kepala Bidang Pembinaan Sekolah Dasar, Kepala Bidang Pembinaan Sekolah Menengah Pertama, Kepala Bidang Kebudayaan, Kepala Bidang Pembinaan Ketenagaan, Seksi Kelembagaan dan Sarana Prasarana (PAUD dan Pendidikan Non Formal), Seksi Peserta Didik dan Pembangunan Karakter, Seksi Kurikulum dan Penilaian, Seksi Kelembagaan dan Sarana Prasarana (Pembinaan Sekolah Menengah Pertama), Seksi Sejarah dan Tradisi, Seksi Kesenian dan Budaya, dan Seksi Pendidikan dan Tenaga Kependidikan. Pengambilan subjek tersebut hanya berdasarkan fokus penelitian, yaitu Kepala dinas, sedangkan subjek lainnya hanya sebagai penguatan data. Sedangkan teknik pengambilan sampel/subjek menggunakan teknik purposive sampling, yaitu dipilih berdasarkan kriteria yang telah ditentukan oleh peneliti tersebut.

Instrumen dalam penelitian ini terdiri dari pedoman observasi dan pedoman wawancara yang bersifat umum dan terbuka sebagai sumber data primer. Sedangkan sumber data sekunder diperoleh dari hasil studi dokumen yang relevan. Teknik pengumpulan data menggunakan teknik observasi (pengamatan), wawancara, dan dokumentasi. Teknik analisis data menggunakan teknik analisis deskriptif kualitatif, yaitu untuk mengkaji gambaran potensial sesuai dengan rumusan penelitian tentang kepemimpinan Kepala Dinas dalam meningkatkan kinerja pegawai pada Dinas Pendidikan Kota Banda Aceh dengan langkah mereduksi data, penyajian data, dan verifikasi data atau penarikan kesimpulan.

\section{HASIL DAN PEMBAHASAN}

\section{Program Kepemimpinan Kepala Dinas Pendidikan Kota Banda Aceh Dalam Meningkatkan Kinerja Pegawai}

Mengenai program yang dijalankan oleh oleh Kepala Dinas, terdapat beberapa program diantaranya: peningkatan disiplin pegawai, apel rutin 
setiap pagi senin, memberikan arahaarahan dan motivasi kerja kepada seluruh pegawai. Selain itu melaksanakan rapat pada hari selasa. Rapat ini dilakukan untuk membuka ruang diskusi dengan pegawai. Program selanjutnya yaitu mewajibkan setiap bidang membuat worksheet yang kemudian pada rapat rutin hari selasa dilaporkan kepada Kepala Dinas. Melalui worksheet Kepala Dinas mengontrol seluruh kinerja pegawai. Program lain yaitu menindaklanjuti program yang sudah ditetapkan oleh Pemerintah Kota (Pemkot) mengenai peningkatan kedisiplinan dan kinerja pegawai yaitu menerapkan sistem absensi berbasis digital yaitu menggunakan aplikasi scan wajah. Kemudian program lain yaitu mengadakan seminar, pelatihanpelatihan, dan workshop.

Kemudian mengenai keterlibatan pegawai dalam penyusunan program meningkatkan kinerja pegawai, kepala dinas selalu melibatkan seluruh pegawai dalam menyusun sebuah program. Baik program pokok dinas maupun program internal. Hal ini dilakukan agar program yang disusun benar-benar tepat sasaran dan diterima oleh semua pegawai. selain itu, mengenai kapan dan berapa lama waktu yang dibutuhkan kepala dinas dalam penyusunan program, kepala dinas menyusun program setiap awal tahun sesuai dengan aturan yang sudah ditetapkan oleh Pemkot maupun kementerian terkait. Masalah lama waktu penyusunan biasanya dilakukan pada bulan januari sampai april termasuk program internal kantor seperti program peningkatan kinerja pegawai.

Pada permasalahan program selanjutnya, mengenai apa yang menjadi sasaran dalam pelaksanaan program mengenai meningkatkan kinerja pegawai, yaitu kedisiplinan, etos kerja, dan juga kemampuan pegawai dalam

melaksanakan tugas. Dengan demikian Kepala Dinas sangat setuju dengan sistem absensi sekarang ini, sehingga tingkat kedisiplinan pegawai dapat meningkat. Dengan demikian kinerja pegawai akan lebih baik. Selain itu Kepala Dinas juga menuntut pegawai untuk mampu meningkatkan soft skill dibidang teknologi karena sekarang ini merupakan era digital agar Dinas Pendidikan Kota Banda Aceh mampu beradaptasi.

Berdasarkan hasil tersebut mengungkapkan bahwa program kepemimpinan Kepala Dinas dalam meningkatkan kinerja pegawai adalah dengan menggunakan gaya kepemimpinan demokratis dan tegas. Kepala Dinas dalam melihat kinerja pegawai harus mampu meningkatkan kedisiplinan dengan melihat tingkat kedisiplinan pegawai dalam melaksanakan tugas yang dibebankan. Pengawasan terhadap pegawai juga dilakukan untuk melihat apakah para pegawai bekerja sesuai dengan worksheet yang sudah dibuat oleh setiap bidang dan melihat apakah pegawai bekerja SOP.

Disadari bahwa disiplin kerja adalah reaksi mental dan emosional dari seseorang terhadap pekerjaannya. Seseorang memiliki disiplin kerja yang tinggi apabila merasa puas terhadap pekerjaannya, apabila Kepala Dinas Pendidikan Kota Banda Aceh ingin meningkatkan disiplin kerja pegawai, ia harus memperhatikan kesejahteraan pegawainya. Dalam meningkatkan kinerja, pegawai terutama harus disiplin dalam melaksanakan tugas, pimpinan membantu pegawai mengembangkan pola perilaku, meningkatkan standar perilakunya, menumbuhkan rasa kebersamaan. Dengan demikian, pola perilaku kelompok erat hubungannya dengan tujuan organisasi. Hal ini, sejalan dengan pendapat Robbins, Stephen, \& Coutler (2016) yang menyatakan bahwa perilaku organisasi adalah studi mengenai apa yang orangorang lakukan dalam sebuah organisasii dan bagaimana perilaku mereka mempengaruhi kinerja organisasi. Pendapat yang sama juga dikemukakan oleh Wijaya (2017) mengemukakan bahwa perilaku organisasi suatu disiplin ilmu yang mempelajari tingkah laku individu dalam organisasi serta dampaknya terhadap kinerja baik kinerja individual, kelompok ataupun organisasi. 
Ada beberapa hal yang harus diperhatikan oleh pimpinan dalam meningkatkan disiplin pegawai yaitu: (1) membantu pegawai mengembangkan pola perilakunya, (2) membantu pegawaii meningkatkan standar perilakunya dan (3) menggunakan pelaksanaan aturan sebagai alat. Lebih lanjut Wijaya (2017) juga mengatakan bahwa pentingnya disiplin pegawai untuk menambah rasa hormat terhadap wewenang, upaya menanam kerja sama, kebutuhan untuk berorganisasi, dan rasa hormat terhadap orang lain. Lebih jelas mengenai Program Kepemimipinan Kepala Dinas dalam meningkatkan kinerja pegawai dapat dilihat pada Tabel 1.

Tabel 1. Program Kepemimipinan Kepala Dinas

\begin{tabular}{|c|c|}
\hline Indikator & Hasil Penelitian \\
\hline $\begin{array}{l}\text { Program yang } \\
\text { disusun Kepala } \\
\text { Dinas }\end{array}$ & $\begin{array}{ll}\text { - } & \begin{array}{l}\text { Peningkatan } \\
\text { kedisipilinan }\end{array} \\
\text { (Apel rutin senin, } & \text { absensi berbasis } \\
\text { digital) } \\
\text { - } \\
\text { Rapat rutin } \\
\text { mingguan } \\
\text { - Pegawai wajib } \\
\text { membuat } \\
\text { - } \text { Sorksheet } \\
\text { - } \text { Peminar } \\
\text { - } \text { Workshop } \\
\end{array}$ \\
\hline $\begin{array}{l}\text { Keterlibatan } \\
\text { pegawai } \\
\text { menyusun } \\
\text { program }\end{array}$ & $\begin{array}{ll}\text { - } & \text { Sekretaris } \\
\text { - } & \text { Kasubag } \\
\text { - } & \text { Kabid } \\
\text { - } & \text { Seluruh pegawai }\end{array}$ \\
\hline $\begin{array}{l}\text { Waktu } \\
\text { penyusunan } \\
\text { program }\end{array}$ & $\begin{array}{ll}\text { - } & \text { Awal tahun } \\
\text { (januari-april) }\end{array}$ \\
\hline $\begin{array}{l}\text { Sasaran } \\
\text { pelaksanaan } \\
\text { Program }\end{array}$ & $\begin{array}{ll}\text { - } & \text { Kedisiplinan, } \\
\text { - } & \text { Etos kerja, } \\
\text { - } & \text { Kemampuan } \\
& \text { menyelesaikan } \\
& \text { tugas } \\
\text { - } & \text { Penguasaan } \\
& \text { teknologi }\end{array}$ \\
\hline
\end{tabular}

\section{Strategi Kepemimpinan Kepala Dinas Pendidikan Kota Banda Aceh Dalam Meningkatkan Kinerja Pegawai}

Mengenai bagaimanakah strategi kepemimpinan Kepala Dinas dalam meningkatkan kinerja pegawai diperoleh hasil bahwa Kepala Dinas harus dapat menyesuaikan terlebih dahulu dengan aturan yang berlaku, mengenai aturanaturan yang sudah ditetapkan oleh Pemkot tentang kedisiplinan. Kemudian Kepala Dinas mengunjungi setiap bidang untuk melihat kinerja dan setiap hari selasa meminta laporan berdasarkan worksheet yang sudah dikerjakan oleh setiap bidang untuk melihat capaian dan menanyakan apa yang menjadi kendala. Kemudian Kepala Dinas juga memberikan keteladanan, meningkatkan etos kerja, pencapaain target, memberikan penghargaan kepada pegawai yang memiliki kinerja baik, dan membangun hubungan kebersamaan.

Kemudian mengenai siapa saja yang terlibat dalam pelaksanaan strategi untuk meningatkan kinerja pegawai diperoleh hasil bahwa Kepala Dinas selaku pemimpin selalu melibatkan Sekretaris, Kasubag dan Kabid untuk menjalankan strategi tersebut, dan pada bagian eksternal Kepala Dinas melibatkan Majelis Pendidikan (MPD) yang mempunyai tugas mengawasi berjalannya Dinas Pendidikan dan juga meminta pendapat terhadap perbaikan-perbaikan untuk meningkatkan kinerja pegawai. Kemudian Kepala Dinas juga dibimbing oleh Asisten 1 sebagai penanggung jawab berjalannya Dinas Pendidikan Kota Banda Aceh.

Indikator lainnya pada masalah strategi, yaitu mengenai apakah strategi Kepala Dinas dalam meningkatkan kinerja pegawai sudah berjalan dengan baik diperoleh hasil bahwa strategi yang lakukan oleh Kepala Dinas sudah berjalan dengan baik walaupun belum sepenuhnya. Oleh karena itu Kepala Dinas dapat menghadirkan berbagai macam prestasi baik tingkat daerah maupun tingkat nasional, kemudian setiap tahun Dinas Pendidikan diberikan anggaran hampir 400 milyar dan dapat diselesaikan sampai $97 \%$, serta dapat mendatangkan sumber dana tingkat nasional untuk membantu Dinas Pendidikan, maka dapat dikatakan bahwa strategi yang dilakukan untuk meningkatkan kinerja pegawai sudah 
berjalan dengan baik walaupun belum sepenuhnya.

Berdasarkan hasil temuan yang diperoleh Kepala Dinas memiliki beberapa strategi yang dijalankannya untuk meningkatkan kinerja pegawai di Dinas Pendidikan Kota Banda Aceh. Mulai dari pendekatan secara kepribadian maupun penetapan aturan-aturan tertulis. Seperti yang diketahui bahwa strategi merupakan alat untuk mencapai tujuan jangka panjang, merupakan tindakan potensial yang membutuhkan keputusan manajemen tingkat atas dan sumber daya perusahaan/organisasi dalam jumlah besar.

Selain itu ditegaskan bahwa strategi mempengaruhi kemakmuran perusahaan/organisasi dalam jangka panjang dan berorientasi masa depan. Hal ini sependapat dengan Jauch dan Glueck (1994) dalam Amirullah (2015) strategi adalah rencana yang disatukan, menyeluruh dan terpadu yang mengaitkan keungggulan strategi perusahaan dengan tantangan lingkungan dan yang dirancang untuk memastikan bahwa tujuan utama perusahaan dapat dicapai melalui pelaksanaan yang tepat oleh perusahaan. Hasil tersebut menunjukkan bahwa Kepala Dinas dalam meningkatkan kinerja pegawai dilakukan dengan melakukan pendekatan dengan pegawai, memberikan arahan-arahan dan memotivasi pegawai untuk menyelesaikan tugas sebagaimana mestinya.

Selain itu, pada kegiatan rapat rutin mingguan yang dilakukan untuk melakukan diskusi dengan seluruh pegawai, Kepala Dinas juga tidak hanya menerima laporan kinerja melalui laporan tertulis, melainkan terjun langsung mengontrol kinerja pegawai. Selain itu memberikan informasi dengan menggunakan bahasa yang mudah dimengerti, serta memberikan penghargaan kepada pegawai yang memiliki kinerja baik.

Berdasarkan strategi tersebut pemimpin ingin lebih menghormati, melindungi dan menghargai pegawai sehingga dapat meningkatkan kinerja pegawai terhadap tugas sehingga pegawai akan bekerja keras dalam menyelesaikan tupoksinya dengan baik. Hasil tersebut juga menunjukkan bahwa dalam menetapkan strategi, Kepala Dinas tidak hanya memberikan aturan dengan garis besar ukuran kerja yang harus diselesaikan. Kepala Dinas menjalankan tugas untuk memotivasi terhadap pegawainnya agar memiliki dedikasi atas pekerjaannya. Bentuk motivasi adalah dengan memberikan insentif berdasarkan jumlah pekerjaan. Maka dari itu segala hambatan yang ditemui dapat dilakukan penanggulangan secara baik dengan memilih alternatif lain agar tercapainya pelaksanaan tujuan dan sasaran strategi organisasi.

Hal ini seperti yang dijelaskan oleh Al-barqi (2015) bahwa motivasi bermanfaat bagi organisasi, karena motivasi berfungsi sebagai penggerak, pengarah, dan pendorong terjadinya perbuatan. sehingga strategi kepemimpinan merupakan sarana yang sangat penting yang digunakan untuk memperoleh kesuksesan atau keberhasilan dalam mencapai tujuan akhir atau sasaran.

Sejalan dengan hasil temuan Istiharoh (2013) bahwa strategi yang dapat dilakukan untuk meningkatkan kinerja pegawai diantaranya: memberikan motivasi kepada pegawai, melakukan pembagian tugas, melakukan diskusi dengan pegawai, memberikan keteladanan, memberikan penghargaan, dan memberikan hukuman.

Selain itu hasil penelitian ini juga sesuai dengan hasil penelitian Izzakyya (2019) yang menyimpulkan bahwa strategi yang dapat dilakukan dalam meningkatkan kinerja pegawai yaitu dengan menerapkan peraturan kedisiplinan, memberikan job description yang jelas, membangkitkan motivasi pegawai, membuat laporan harian, dan memberikan reward dan phunisment. Lebih jelas mengenai strategi Kepemimipinan Kepala Dinas dalam meningkatkan kinerja pegawai dapat dilihat pada Tabel 2. 
Tabel 2. Strategi Kepemimipinan Kepala Dinas

\begin{tabular}{|c|c|}
\hline Indikator & Hasil Penelitian \\
\hline $\begin{array}{l}\text { Strategi yang } \\
\text { diterapkan }\end{array}$ & $\begin{array}{ll}\text { - } & \text { Pendekatan } \\
\text { dengan } \\
\text { pegawai } \\
\text { - } \text { Meminta } \\
\text { laporan kinerja } \\
\text { setiap rapat } \\
\text { mingguan } \\
\text { - } \text { Memotivasi } \\
\text { - Memberi } \\
\text { keteladanan } \\
\text { - } \text { memberi } \\
\text { penghargaan }\end{array}$ \\
\hline $\begin{array}{l}\text { Keterlibatan } \\
\text { pelaksanaan } \\
\text { strategi }\end{array}$ & $\begin{array}{ll}\text { - } & \text { Sekretaris } \\
\text { - } & \text { Kasubag } \\
\text { - } & \text { Kabid }\end{array}$ \\
\hline $\begin{array}{l}\text { Keterlaksanaan } \\
\text { strategi }\end{array}$ & $\begin{array}{ll}\text { - } & \text { berjalan } \\
& \text { dengan baik }\end{array}$ \\
\hline
\end{tabular}

Hambatan Kepemimpinan Kepala Dinas Pendidikan Kota Banda Aceh Dalam Meningkatkan Kinerja Pegawai

Mengenai hambatan yang diperoleh Kepala Dinas dalam meningkatkan kinerja pegawai di Dinas Pendidikan Kota Banda Aceh diperoleh hasil yaitu mengenai Sumber Daya Manusia (SDM) yang dimiliki sangat terbatas, karena pegawai tidak ingin meningkatkan kemampuan diri. Maka dari itu mereka juga bekerja lebih banyak menyelesaikan tugas masingmasing dan kurang mempunyai kreativitas, kemudian terdapat beberapa pegawai yang kurang mampu menguasai teknologi, hal ini disebabkan oleh faktor umur dan hal-hal lainnya. Kemudian mengenai bagaimana cara kepala dinas dalam mengatasi hambatan dalam meningkatkan kinerja pegawai diketahui bahwa cara yang dilakukan dengan megadakan dan mengikutsertakan pegawai mengikuti pembinaan, diklat, workshop, seminar dan pelatihanpelatihan lainnya. Kemudian pada setiap rapat juga meminta kepada pegawai untuk menyampaikan kendala-kendala yang dihadapi.

Selain itu Kepala Dinas melakukan pendekatan dengan para pegawai, sering berkomunikasi, diskusi tentang permasalahan yang ada, dengan demikian maka kualitas pegawai akan meningkat dan tupoksinya akan berjalan dengan lancar. Lain dari itu Kepala Dinas juga selalu membudayakan kebersamaan ddan keakraban dengan pegawai.

Selanjutnya mengenai apa saja bentuk hukuman/sanksi yang diberikan oleh Kepala Dinas terhadap pegawai yang melanggar aturan yang telah ditetapkan, diperoleh hasil bahwa pegawai yang melanggar aturan seperti tidak hadir berturut-turut selama 3 (tiga) hari maka akan ditegur secara tertulis, kemudian dipanggil dan dinasehati, bila masih melanggar maka akan dikirimkan ke Badan Kepegawaian dan Pengembangan Sumber Daya Manusia (BPKSDM), jadi pihak Pemerintah Kota melalui BPKSDM akan melakukan pembinaan, bahkan dimutasi dan diskor. Hal dilakukan oleh pihak Pemerintah Kota Banda Aceh, Kepala Dinas hanya melaporkan saja berdasarkan absen atau surat teguran-teguran lainnya.

Dari hasil tersebut menunjukkan bahwa terdapat beberapa kendala yang dihadapi oleh Kepala Dinas Pendidikan Kota Banda Aceh diantaranya masih rendahnya kompetensi pegawai sedangkan beban kerja tinggi sehingga pegawai perlu diberi pelatihan, dibimbing dan dibina. Hal ini dapat terjadi karena pegawai tidak memiliki keinginan untuk melanjutkan studinya untuk memperdalam pengetahuan dan mempelajari sesuatu yang baru. Selain itu kurangnya kreativitas pegawai dalam menyelesaikan tugas. Pegawai menyelesaikan tugas secara monoton dan tidak melakukan dengan cara-cara lain. Padahal dewasa ini teknologi dapat digunakan untuk membantu kegiatan sehari-hari seperti penggunaan aplikasiaplikasi tertentu yang diperlukan. Hal ini seperti yang dijelaskan oleh Menpan (2015) bahwa perlu membangun birokrasi yang lebih efisien dan efektif dalam menjawab segalah perkembangan situasi dan kondisi yang ada dalam masyarakat. Pembangunan birokrasi dan inovasi harusnya bisa dilakukan dengan memberikan perhatian serius kepada penerapan e-government. Salah satu yang memberikan harapan adalah adanya kerjasama dengan Korea Selatan yang dianggap berhasil dalam 
menerapakan teknologi informasi dalam percepatan reformasi birokrasi.

Keterbatasan kompetensi dan penguasaan teknologi oleh pegawai di Dinas Pendidikan Kota Banda aceh karena faktor usia yang sudah lanjut. Seperti yang diketahui bahwa usia merupakan salah satu penghambat dalam hal peningkatan kemampuan baik hard skill maupun soft skill. Hal inilah suatu kendala mempengaruhi kinerja pegawai. Namun tentu bukanlah suatu permasalahan yang paling vital hingga mengganggu tugas pokok dinas karena tidak semua pegawai di Dinas Pendidikan Kota Banda Aceh sudah berusia lanjut melainkan juga memiliki tenaga pegawai yang masih muda dan menguasai teknologi. Hanya saja bagi pegawai yang sudah berusia lanjut memerlukan waktu lebih lama untuk menyesuaikan dengan perkembangan sekarang ini dan memerlukan waktu untuk belajar lebih lama. Selain itu faktor-faktor yang dihadapi oleh Kepala Dinas yaitu permasalahan pribadi pegawai, dimana pegawai harus meminta izin untuk tidak masuk kerja karena faktor keluarga. Misalnya ada salah satu anggota keluarga yang sakit, merawat orang tua yang sudah lanjut usia, dan alasan-alasan lainnya. Hal ini tentu menjadi salah satu faktor penghambat peningkatan kinerja pegawai oleh Kepala Dinas karena pegawai tidak dapat menyelesaikan masalah pribadi. Hal sesuai dengan pendapat Questibrilia (2019) yang menjelaskan bahwa masalah pribadi pegawai seringkali membuat kinerja pegawai menjadi menurun sehingga pekerjaan tidak lagi dijalankan secara maksimal. Suatu masalah seringkali terjadi di lingkungan kerja sehingga kondisi ini bisa memberikan dampak buruk baik bagi pegawai yang mengalami masalah itu sendiri maupun bagi perusahaan/kantor. Tentu saja hal ini pada akhirnya mengakibatkan terjadinya banyak hambatan atau kendala selama proses pekerjaan berlangsung. Akhirnya pekerjaan pun tidak bisa berjalan secara maksimal karena pegawai tidak berfokus pada pakerjaannya.
Demikian, faktor penghambat tersebut bukan merupakan sebuah penghambat yang berarti. Pada permasalahan ini Kepala Dinas masih bisa mengatasinya melalui pendekatanpendekatan yang dilakukan baik secara langsung maupun tidak langsung. Kepala Dinas melakukan pendekatan seperti melakukan diskusi tertutup dengan pegawainya untuk mempertanyakan permasalahan yang terjadi, mencari solusi, memberi nasehat, dan memotivasinya. Adapun mengenai faktor penghambat peningkatan kinerja pegawai di Dinas Pendidikan Kota Banda Aceh, Kepala Dinas tidak mengalami hambatan yang berarti. Hal ini dapat diketahui berdasarkan data yang diperoleh bahwa beberapa hambatan yang sering dihadapi oleh Kepala Dinas dapat diatasi dengan baik.

Hasil penelitian ini sesuai dengan hasil penelitian yang dilakukan oleh Maulana et al., (2020) yang menyatakan bahwa hambatan yang dihadapi pemimpin dalam meningkatkan kinerja pegawai yaitu mengenai tingkat pendidikan pegawai yang masih rendah, tingkat pengetahuan dan kreativitas pegawai yang yang terbatas, dan kurangnya inovasi pegawai terhadap pelayanan masyarakat. Selain itu hasil serupa juga ditemukan oleh Lestari et al., (2015) bahwa hambatan pemimpin dalam meningkatkan kinerja pegawai diantaranya mengenai perbedaan latar pendidikan antara pemimpin dan pegawai sehingga terjadinya perbedaan pemahaman, masalah pribadi yaitu mengenai keterbatasan ekonomi pegawai, pengetahuan, dan wawasan pegawai dalam bekerja.

Lebih jelas mengenai Hambata Kepemimipinan Kepala Dinas dalam meningkatkan kinerja pegawai dapat dilihat pada Tabel 3.

Tabel 3. Hambatan Kepemimipinan Kepala Dinas

\begin{tabular}{|l|ll|}
\hline \multicolumn{1}{|c|}{ Indikator } & Hasil Penelitian \\
\hline Hambatan & $\bullet$ & Keterbatasan SDM \\
& $\bullet$ & Kurang kreatif \\
& $\bullet$ & Keterbatasan \\
& teknologi \\
\hline
\end{tabular}




\begin{tabular}{|l|lll|}
\hline Solusi & $\bullet$ & Pelatihan & \\
& $\bullet$ & Seminar \\
& $\bullet$ & Workshop & \\
& $\bullet$ & Diskusi & \\
\hline Sanksi & $\bullet$ & Teguran lisan & \\
& $\bullet$ & Teguran tertulis & \\
& & Pelaporan & ke \\
& & BPKSDM & \\
\hline
\end{tabular}

\section{SIMPULAN DAN SARAN}

Program kepemimpinan Kepala Dinas Pendidikan Kota Banda Aceh dalam meningkatkan kinerja pegawai diantaranya melaksanakan kegiatankegiatan seminar, workshop, pelatihan, apel setiap pagi senin. Penyusunan program juga melibatkan seluruh pegawai, sedangkan waktu penyusunan program dilakukan pada awal tahun. Sasaran program yang disusun adalah untuk meningkatkan kedisiplinan, etos kerja, semangat kerja, pencapaian target, dan kerjasama pegawai. Strategi kepemimpinan Kepala Dinas Pendidikan Kota Banda Aceh dalam meningkatkan kinerja pegawai diantaranya: kedisiplinan, etos kerja, memberikan reward dan sanksi, memberikan motivasi, dan kerjasama. Hambatan yang dihadapi oleh Kepala Dinas Pendidikan Kota Banda Aceh dalam meningkatkan kinerja pegawai diantaranya keterbatasan Sumber Daya Manusia (SDM), pegawai tidak ingin melanjutkan studi mereka ke jenjang yang lebih tinggi agar dapat meningkatkan kemampuan diri, pegawai lebih banyak menyelesaikan tugas di bandingkan harus memikirkan kualitas tugas yang dikerjakannya, keterbatasan penggunaan teknologi.

Saran yang dapat diusulkan yaitu Kepala Dinas agar dapat mempertahankan dan meningkatkan kepemimpinan yang sudah dijalankan selama ini dengan baik dan terstruktur. Agar kinerja pegawai dapat terus menyelesaikan tugasnya dan mampu meningkatkan kualitas pendidikan di Kota Banda Aceh. Harapan Kepala Dinas terus melakukan evaluasi atas kelemahan yang kepemimpinan yang dilaksanakan selama ini agar lebih sempurna kedepannya. Kemudian Kepala Dinas agar terus melaksanakan kepemimpinan yang demokratis agar terciptanya iklim kerja yang kondusif dan tidak menjadi suatu permasalahan bagi pegawai atas program-program yang dijalankannya. Selain itu agar Kepala Dinas agar terus melakukan inovasi-inovasi sesuai dengan perkembangan zaman dewasa ini supaya Dinas Pendidikan Kota Banda Aceh tetap eksis dalam menjawab tantangan permasalahan pendidikan di Kota Banda Aceh.

\section{DAFTAR PUSTAKA}

\section{Al-Barqy, A. A. (2015). Strategi} Kepemimpinan Dalam Meningkatkan Kinerja Pegawai di Kementerian Agama Kota Malang. Malang: Pasca Sarjana UIN Maulana Malik Ibrahim Malang. Retrieved from http://etheses.uinmalang.ac.id/3530/1/13710037.pdf

Amirullah. (2015). Pengantar Manajemen. Jakarta: Mitra Wacana Media.

Frayudha, A.D., Slamet, A., \& Awalya. (2016). Pengaruh Kepemimpinan Kepala Dinas dan Kompensasi Melalui Motivasi Kerja Terhadap Kinerja Pegawai Dinas Pendidikan Kabupaten Rembang. Journal of Educational Management. 4(4): 1-9.

Hamalik, O. (2016). Manajemen Sumber Daya Manusia. Jakarta: Erlangga.

Istiharoh, R. (2013). Peran Kepemimpinan Dalam Peningkatan Kinerja Pegawai di Badan Penanaman Modal Daerah (BPMD) Kabupaten Kutai Timur. Jurnal Administrasi Reform, 1(1): 151-169.

Izzakyya, N. (2019). Strategi Kepemimpinan Dalam Meningkatkan Kinerja Pegawai di Kantor Kementerian Agama Kab. Grobogan. Semarang: Fakultas IImu Tarbiyah dan Keguruan Universitas Islam Negeri Walisongo Semarang. Retrieved from https://eprints.walisongo.ac.id/1233 4/1/SKRIPSI 1503036056 NISA\%2 OlZZAKYYA.pdf

Lestari, R.P., Hardjanto, I., \& Said, A. (2015). Kepemimpinan Camat dalam Meningkatkan Kinerja Pegawai (Studi Pada Kecamatan Mojoroto Kota Kediri). Jurnal 
Administrasi Publik (JAP), 3,(1): 157-164.

Maulana, M.R., Wahid, A., \& Fibriyanita, F. (2020). Peran Kepemimpinan Dalam Meningkatkan Kinerja Pegawai di Kantor Badan Kesatuan Bangsa dan Politik Kota Banjarmasin. Banjarmasin: Prodi IImu Administrasi Publik, FISIP, Universitas Islam Kalimantan. Retrieved from http://eprints.uniskabjm.ac.id/3437/

Menpan. (2015). Peraturan Menteri Pendayagunaan Aparatur Negara dan Reformasi Birokrasi Republik Indonesia Nomor 15 Tahun 2015 tentang Kompetisi Inovasi Pelayanan Publik di Lingkungan Kementerian, Lembaga, dan Pemerintah Daerah tahun 2016. Jakarta: Menteri Pendayagunaan Aparatur Negara dan Reformasi Birokrasi. Retrieved from https://jdih.menpan.go.id/data_puu/ 15.pdf

Questibrilia, B. (2019). Seberapa Pentingkah Onboarding dalam Perusahaan. Retrieved from https://www.jojonomic.com/blog/onb oarding/

Robbins, S.P., \& Mary. C. (2016). Human Resources Management, Edisi 16, Jilid 1. Jakarta: Salemba Empat.

Wahyudi. (2017). Manajemen Konflik dan Stres dalam Organisasi Pedoman Praktis bagi Pemimpin Visioner. Bandung: Alfabeta.

Wijaya, C. (2017). Perilaku Organisasi. Medan: Lembaga Peduli Pengembangan Pendidikan Indonesia (LPPPI). 